\title{
Evaluation of Nutritional Ingredients, Biologically Active Materials, and Pharmacological Activities of Stropharia rugosoannulata Grown under the Bamboo Forest and in the Greenhouse
}

\author{
Lei Wei $\mathbb{D}^{1},{ }^{1}$ Bingnian Jing, ${ }^{1}$ Xiao Li, ${ }^{1}$ Yueying Hou, ${ }^{2}$ Xiaoyang Xie,, ${ }^{1}$ hiyao Wang, \\ Yuqing Liu, ${ }^{1}$ Yong Zhou, ${ }^{1}$ Xia Chang, ${ }^{1}$ and Wei Wang ${ }^{1}{ }^{1}$ \\ ${ }^{1}$ Key Laboratory of Natural Products, Henan Academy of Sciences, Zhengzhou 450002, China \\ ${ }^{2}$ Electric Power Engineering School, Zhengzhou Electric Power College, Zhengzhou 450002, China \\ Correspondence should be addressed to Wei Wang; bioww@foxmail.com
}

Received 1 November 2021; Accepted 24 November 2021; Published 11 December 2021

Academic Editor: Fatma M. El-Demerdash

Copyright (C) 2021 Lei Wei et al. This is an open access article distributed under the Creative Commons Attribution License, which permits unrestricted use, distribution, and reproduction in any medium, provided the original work is properly cited.

\begin{abstract}
Evaluations of the nutritional ingredients, biologically active materials, and pharmacological activities (antibacterial and antioxidant) of two types of Stropharia rugosoannulata, grown under the bamboo forest and in the greenhouse, respectively, were carried out in this study. The nutritional ingredient tests included moisture, ash, crude protein, crude fat, crude fiber, total carbohydrates, total sugar, mineral elements, vitamins, and amino acids. The biologically active material assays included total flavonoids, total polysaccharides, total triterpenoids, and reducing sugars. In addition, a broth microdilution susceptibility test was performed to evaluate antibacterial activity. The antioxidant activity was measured by $\mathrm{ABTS}^{+}$radical scavenging, ferric-reducing power, and $\beta$-carotene bleaching assays. Results showed that two types of $S$. rugosoannulata were rich in protein, carbohydrate, fiber, mineral, B-group vitamins, polysaccharides, triterpenoids, and reducing sugars, with low content of fat and low $\mathrm{Na} / \mathrm{K}$ ratio. Besides, they were effective in antibacterial and antioxidant activities, while S. Rugosoannulata grown under the bamboo forest was better than the greenhouse one in some respects such as higher content of protein, calcium, selenium, nicotinic acid, folic acid, polysaccharides and triterpenoids, and stronger antibacterial and antioxidant activities. They were appropriate for functional food and nutritional supplements, especially bamboo forest.
\end{abstract}

\section{Introduction}

Stropharia rugosoannulata, belonging to the family of Strophariaceae, has a worldwide distribution in northern temperature zones and is edible and can be cultivated for food [1] due to its rich nutrition and pleasant flavor. It is one of the top ten mushrooms internationally traded and recommended to developing countries by the UN Food and Agriculture Organization [2, 3]. It has some important pharmacological activities such as antitumor, antioxidative, and antihyperglycemic effects and also has preventative effects on coronary heart diseases $[4,5]$.

S. rugosoannulata is easy to cultivate and can be cultivated with different kinds of raw materials such as sawdust, straw, corncob rice, and husk [6-8]. But now, cultivating mushrooms in forest lands has been encouraged by the Chinese government, because it can efficiently use the large expanses of space under the woods. So S. rugosoannulata has been cultivated under the forest in several Chinese provinces, including Shandong, Fujian, Yunnan, and Henan $[9,10]$. In Bo'ai County of Henan province, the bamboo forest has a thousand-year history of cultivation, known as the "living fossil of an artificial bamboo forest in northern China." Based on the abundant bamboo resources, the people living here make efforts to develop the S. rugosoannulata cultivation industry and have achieved good economic and ecological benefits. But the nutritional ingredients, biologically active materials, and some 
pharmacological activities in view of the S. rugosoannulata grown under the bamboo forest in Bo'ai County have been scarcely reported.

Therefore, the aim of this study was to evaluate the nutritional ingredients and biologically active materials of S. rugosoannulata grown under the bamboo forest in Bo'ai County, compared with $S$. rugosoannulata cultivated in the greenhouse. Furthermore, the antibacterial and antioxidant activities of two kinds of extractions (aqueous and ethanolic) obtained from these two types of mushrooms were tested and compared.

\section{Materials and Methods}

2.1. Chemicals and Reagents. 2,2'-Azinobis-(3-ethylbenzothiazoline-6-sulfonic acid) $\left(\mathrm{ABTS}^{+}\right)$, 2,4-dinitrofluorobenzene (DNFB), 2,6-di-tert-butyl-4-methylphenol (BHT), dimethyl sulfoxide (DMSO), rutin, ursolic acid, glucose, and ascorbic acid $\left(V_{c}\right)$ were obtained from SigmaAldrich (Germany). All other chemicals and solvents were of the highest commercial grade and obtained from Sinopharm Chemical Reagent Co., Ltd. (Shanghai, China).

2.2. Materials. Two types of S. rugosoannulata were collected under the bamboo forest and in the greenhouse from Bo'ai County in July 2020, abbreviated as BFSR and GHSR, respectively. The district is a warm temperate, continental monsoon climate characterized by hot, rainy summers, and cold and dry winters, with an annual mean temperature of $14.1^{\circ} \mathrm{C}$, sunshine time of 2432.6 hours, and precipitation of $597.1 \mathrm{~mm}$, while the temperature and humidity in the greenhouse were kept at about $26^{\circ} \mathrm{C}$ and $80-90 \%$, respectively. The basic materials included $40 \%$ corn stalks, $30 \%$ corncobs, $20 \%$ rice husks, and $10 \%$ sawdust, which formed a mixture. Their moisture content was maintained at 70-75\% and $\mathrm{pH}$ at 6-6.5 when paved. The identification was confirmed by Prof. Chengming Dong, a taxonomist from the Henan University of Chinese Medicine. The mushrooms were cleaned with a plastic knife and transported back to the laboratory as soon as possible. They were freeze-dried and powdered through a 40 mesh sieve. Ten kinds of bacteria were as follows: Escherichia coli (ATCC 25922), Streptococcus pneumoniae (ATCC 49619), Staphylococcus aureus (ATCC 29213), Pseudomonas aeruginosa (ATCC 27853), Salmonella typhimurium (ATCC 13311), Klebsiella pneumoniae (ATCC 700603), and Streptococcus pyogenes (ATCC 19615) were collected from the Nanjing Bianzhen Biological Technology Co., Ltd., and Salmonella Dublin, Stenotrophomonas maltophilia, and Enterococcus faecalis were preserved in the Key Laboratory of Natural Products, Henan Academy of Sciences.

\subsection{Nutritional Ingredient Test}

2.3.1. Proximate Analysis. The proximate analysis consisted of analytical determinations of moisture, ash, crude protein, crude fat, crude fiber, total carbohydrates, and total sugars as described by AOAC [11]. Moisture content was determined by further heating of the dried sample at $105^{\circ} \mathrm{C}$ overnight until constant weight; ash content was determined by incineration of samples at $550^{\circ} \mathrm{C}$ for $6 \mathrm{~h}$; crude protein content was determined using the nitrogen-to-protein conversion factor of 6.25 [12]; crude fat was gravimetrically analyzed after extraction with diethyl ether using a soxhlet system; crude fiber content was determined by the method reported by Kaur and Asthir [13]; total carbohydrates (\%)= 100 - crude protein - crude fat - ash; total sugar content was measured by the phenol-sulfuric acid method according to Dubois [14].

2.3.2. Mineral Analysis. The mineral composition was determined using inductively coupled plasma optical emission spectrometry (ICP-OES). The samples were ashed in a muffle furnace at $500^{\circ} \mathrm{C}$ over night and digested in diluted nitric acid (7 mol/L) [15]. Phosphorus (P) was determined by molybdenum blue spectrophotometry.

2.3.3. Vitamin Analysis. Fat-soluble vitamins A, D, and E were determined by HPLC [16]. Vitamins $B_{1}, B_{6}$, and $B_{12}$ were determined according to Markopoulou [17]. Vitamin $\mathrm{B}_{2}$ was tested as reported by Petteys [18]. Vitamin $\mathrm{K}_{1}$ was assayed by reverse-phase HPLC [19]. Pantothenic acid (vitamin $\mathrm{B}_{5}$ ) was determined by reverse-phase liquid chromatography-mass spectrometry [20]. Nicotinic acid was determined by HPLC [21]. Folic acid was tested by the reagent kit method.

2.3.4. Amino Acid Analysis. The compositions of amino acids were determined by reverse-phase HPLC according to Robert and Stephen [22] with a little modification. It was equipped with a Phenomenex Gemini NX C18 column $(4.6 \mathrm{~mm} \times 250 \mathrm{~mm}, 5 \mu \mathrm{m})$, with gradient elution at $35^{\circ} \mathrm{C}$ and a flow rate of $1 \mathrm{~mL} / \mathrm{min}$. The gradient of the mobile phase was formed with buffer A $(0.05 \mathrm{~mol} / \mathrm{L}$ sodium acetate, $\mathrm{pH}$ adjusted $6.4 \pm 0.05$ with acetic acid, including $0.1 \% \mathrm{~N}$, $\mathrm{N}$-dimethylformamide) and buffer B (acetonitrile: deionized water $=1: 1, \mathrm{~V} / \mathrm{V})$. The gradient program of the mobile phase is shown in Table 1. 2, 4-dinitrofluorobenzene was used as the precolumn derivation reagent, and detection wavelength was set at UV $360 \mathrm{~nm}$. The stock solutions of individual amino acids were prepared in $0.1 \mathrm{~mol} / \mathrm{L} \mathrm{HCl}$ except tryptophan, which was prepared in water, and the concentration of individual amino acids was approximately $1 \mathrm{mmol} / \mathrm{L}$.

2.4. Biologically Active Material Analysis. The reducing sugar content was determined by the Nelson-Somogyi assay using a microtiter plate [23]; total flavonoid content was determined following a procedure previously described [24]; total triterpenoid content was determined through the vanillinglacial acetic acid system by spectrophotometry [25]; total polysaccharide content was tested by the phenol-sulfuric acid method using D-glucose as the standard [26]. 
TABLE 1: Gradient program of the mobile phase.

\begin{tabular}{lcc}
\hline Time/min & Mobile phase A/\% & Mobile phase $\mathrm{B} / \%$ \\
\hline 0 & 82 & 18 \\
3 & 82 & 18 \\
8 & 72 & 28 \\
20 & 72 & 28 \\
30 & 68 & 32 \\
40 & 68 & 32 \\
55 & 40 & 60 \\
70 & 5 & 95 \\
\hline
\end{tabular}

\subsection{Pharmacological Activity Assays}

2.5.1. Preparation of Aqueous and Ethanolic Extracts. The powders of BFSR and GHSR were used for extraction. The aqueous and ethanolic extracts were prepared as follows: a suitable amount of the mushroom powder was soaked in $95 \%$ ethanol and soxhlation was performed at $75^{\circ} \mathrm{C}$ for $24 \mathrm{~h}$ to obtain the ethanolic extract. For aqueous extract, the powder was macerated in boiled water for $4 \mathrm{~h}$ under constant agitation. Both extracts were filtered using filter papers of pore size $2.5 \mu \mathrm{m}$, dried in a rotary evaporator set to $45^{\circ} \mathrm{C}$, and then stored at $4^{\circ} \mathrm{C}$ for further analysis.

2.5.2. Antibacterial Activity Test. The broth microdilution method for determination of the minimal inhibitory concentration (MIC) values was used according to the Clinical and Laboratory Standards Institute (CLSI) [27]. Concisely, the aqueous extract and ethanolic extract stored at $4^{\circ} \mathrm{C}$ were diluted using the double dilution method, respectively. The concentrations included $16,8,4,2,1,0.5,0.25,0.125,0.0625$, and $0.03125 \mathrm{mg} / \mathrm{mL}$. The bacteria aforementioned were regulated to $\mathrm{OD}_{600}=0.5$ in the beef-protein broth. An equal volume of $100 \mu \mathrm{L}$ sample and $100 \mu \mathrm{L}$ bacterial broth was relatively added to each well in 96-well plates. The plates were covered with lids and incubated at $37^{\circ} \mathrm{C}$ for $24 \mathrm{~h}$. The turbidity and a pellet on the bottom indicated bacterial growth, and the lowest concentration was the MIC value. The lowest concentration at which $99.9 \%$ of the bacteria had been killed was taken as minimal bactericidal concentration (MBC).

2.5.3. Antioxidant Activity Test. 2.5.3.1. ABTS $^{+}$Radical Scavenging Activity. The $\mathrm{ABTS}^{+}$stock solution $(7.0 \mathrm{mmol} / \mathrm{L})$ and potassium persulfate $(2.45 \mathrm{mmol} / \mathrm{L}$ of final concentration) were reacted in the dark at room temperature for $14 \mathrm{~h}$, and this solution was diluted with phosphate-buffered saline $(0.2 \mathrm{mmol} / \mathrm{L}, \mathrm{pH} 7.4)$ to an absorbance of 0.7 at $734 \mathrm{~nm}$. About $100 \mu \mathrm{L}$ diluted $\mathrm{ABTS}^{+}$solution was added to $100 \mu \mathrm{L}$ sample with the concentration from 1 to $20 \mathrm{mg} / \mathrm{mL}$, and the absorbance was tested after $6 \mathrm{~min}$ [28]. The results were expressed as percentage reduction absorbance shown by the sample with respect to $\mathrm{ABTS}^{+}$solution. $V_{\mathrm{c}}$ was used as the positive control at a different concentration $(0.1-0.5 \mathrm{mg} /$ $\mathrm{mL})$. The formula was as follows:

$$
\operatorname{ABTS}^{+} \text {scavenging }(\%)=\left[\frac{(\text { control absorbance }- \text { sample absorbance })}{\text { conrol absorbance }}\right] \times 100
$$

2.5.3.2. Ferric-Reducing Power (FRP). FRP was tested according to the previously reported method [29]. Briefly, $1.0 \mathrm{~mL}$ sample in phosphate buffer $(0.2 \mathrm{~mol} / \mathrm{L}, \mathrm{pH} 6.6)$ and $1.0 \mathrm{~mL} \mathrm{~K} \mathrm{~K}_{3}\left[\mathrm{Fe}(\mathrm{CN})_{6}\right]$ solution $(1.0 \%$, w/v) were fully mixed and heated in a $50^{\circ} \mathrm{C}$ water bath for $20 \mathrm{~min}$ and then added with $1.0 \mathrm{~mL}$ trifluoroacetic acid (TFA, $10.0 \%$, w/v) to terminate the reaction. The supernatant was collected after centrifugation and added with $1.0 \mathrm{~mL}$ ultrapure water and $0.5 \mathrm{~mL} \mathrm{FeCl}_{3}(1.0 \%$, w/v). This mixture was thoroughly mixed and reacted for $10 \mathrm{~min}$ at room temperature. After centrifugation, the absorbance was measured at $700 \mathrm{~nm}$. FRP of samples was expressed using sample absorbances against ultrapure water (a blank), and $V_{\mathrm{c}}$ was used as the positive control at the same concentration $(0.2-4 \mathrm{mg} / \mathrm{mL})$.

2.5.3.3. $\beta$-Carotene Bleaching Assay. The $\beta$-carotene bleaching assay was carried out as previously reported [30]. About $11 \mu \mathrm{L}$ of $1.0 \mathrm{mg} / \mathrm{mL} \beta$-carotene trichloromethane solution was mixed with $4.4 \mu \mathrm{L}$ linoleic acid and $22 \mu \mathrm{L}$ Tween 40. After removing the trichloromethane, the dry mixture was diluted with $2.4 \mathrm{~mL}$ phosphate buffer solution $(0.02 \mathrm{~mol} /$ $\mathrm{L}, \mathrm{pH} 7.01)$ and $0.1 \mathrm{~mL}$ samples $(2 \mathrm{mg} / \mathrm{mL})$. The absorbance at $460 \mathrm{~nm}$ was measured and monitored every $20 \mathrm{~min}$. About $0.1 \mathrm{~mL}$ ethanol $(60 \%, \mathrm{v} / \mathrm{v})$ and BHT instead of samples were used as the negative and positive controls, respectively.
2.6. Statistical Analysis. All assays were performed in triplicate. The results were expressed as mean values \pm standard error (SE). The results were analyzed using a one-way analysis of variance (ANOVA) in SPSS 22.0 with a $95 \%$ confidence interval performed to identify statistically significant differences between BFSR and GHSR, followed by Tukey's post hoc test with $\alpha=0.05$. $P$-values below 0.05 were considered statistically significant and below 0.01 were considered statistically extremely significant.

\section{Results and Discussion}

In this study, levels of the nutritional ingredients and biologically active materials were determined in BFSR and GHSR with an aim to identify whether $S$. rugosoannulata grown under the bamboo forest has more health-promoting nutrients than cultivated one in the greenhouse. In addition, the antibacterial and antioxidant activities were assayed and compared.

\subsection{Nutritional Ingredients}

3.1.1. Proximate Composition. The results of proximate composition are shown in Table 2. It showed that S. rugosoannulata had high levels of crude protein 
TABLE 2: Mean values of proximate composition of BFSR and GHSR.

\begin{tabular}{lcc}
\hline Parameter/\% & BFSR & GHSR \\
\hline Moisture & $11.36 \pm 0.11^{* *}$ & $9.81 \pm 0.24$ \\
Ash & $8.26 \pm 0.05^{* *}$ & $8.91 \pm 0.07$ \\
Crude protein & $33.57 \pm 1.35^{*}$ & $28.77 \pm 0.25$ \\
Crude fat & $1.32 \pm 0.07^{* *}$ & $2.37 \pm 0.04$ \\
Crude fiber & $7.5 \pm 0.08^{* *}$ & $7.97 \pm 0.05$ \\
Total carbohydrates & $43.21 \pm 1.09^{* *}$ & $50.75 \pm 0.29$ \\
Total sugars & $38.39 \pm 0.55$ & $39.35 \pm 0.57$ \\
\hline
\end{tabular}

Notes. Results were expressed as means \pm SE $(n=3)$. ${ }^{*}$ Significant at 0.05 level. ${ }^{* *}$ Extremely significant at 0.01 level.

(28.77-33.57\%) and crude fiber (7.5-7.97\%) but low levels of ash (8.26-8.91\%) and crude fat (1.32-2.37\%) according to the National Food Safety Standard General Rules for $\mathrm{Nu}-$ trition Labeling of Prepackaged Food (GB 28050-2011). Except total sugars, other parameters were significantly different between BFSR and GHSR. Concisely, moisture content of BFSR $(11.36 \pm 0.11 \%)$ was extremely significantly higher than GHSR ( $9.81 \pm 0.24 \%)$; crude protein content of BFSR was significantly higher than that of GHSR, which was much higher than 22 kinds of edible fungi reported by $\mathrm{Yu}$ et al. [31]. The contents of ash, crude fat, crude fiber, and total carbohydrates of BFSR were extremely significantly lower in comparison with GHSR. Total sugar contents were $38.39 \pm 0.55 \%$ and $39.35 \pm 0.57 \%$, respectively. Therefore, S. rugosoannulata has high carbohydrates, high crude proteins, and high crude fibers, but low-ash and low-fat edible fungus, which is in line with people's pursuit of the low-fat healthy diet. By comparison, BFSR was better than GHSR in view of higher content of protein and lower content of fat.

3.1.2. Mineral Content. As shown in Table 3, S. rugosoannulata was a mushroom rich in mineral elements and can be used as a good source of minerals, and the levels of studied mineral elements meet well with the recommended dietary allowances of NRC/NAS [32]. Extremely significant differences were found in all macroelements between BFSR and GHSR. The contents of natrium $(\mathrm{Na})$, potassium $(\mathrm{K})$, magnesium $(\mathrm{Mg})$, and calcium $(\mathrm{Ca})$ in BFSR were $1282.08 \pm 58.35,34196.34 \pm 55.05,1126.46 \pm 3.03$, and $1350.54 \pm 5.84 \mathrm{mg} / \mathrm{Kg}$, respectively, all of which were more than $1000 \mathrm{mg} / \mathrm{Kg}$. The most abundant mineral element was $\mathrm{K}$ both in BFSR and GHSR, which agreed with the previous reports $[5,33]$. The $\mathrm{Na} / \mathrm{K}$ ratios in BFSR and GHSR were 0.037 and 0.020 , respectively, which was very low and indicated that it was an advantage from the nutritional point of view, because the intake of sodium chloride and diets with a high $\mathrm{Na} / \mathrm{K}$ ratio have been related to the incidence of hypertension [34].

The microelement contents including ferrum $(\mathrm{Fe})$, zinc $(\mathrm{Zn})$, and manganese $(\mathrm{Mn})$ were significantly different except copper $(\mathrm{Cu})$. In particular, BFSR had a high content of selenium (Se) $(2.21 \pm 0.09 \mathrm{mg} / \mathrm{Kg})$ but not detected in GHSR. Se is an essential micronutrient for humans and animals and performs important biological functions. Se deficiency has
TABLE 3: Mineral composition of BFSR and GHSR.

\begin{tabular}{|c|c|c|c|}
\hline \multicolumn{2}{|c|}{ Elements $(\mathrm{mg} / \mathrm{Kg})$} & BFSR & GHAR \\
\hline \multirow{5}{*}{ Macroelement } & $\mathrm{Na}$ & $1282.08 \pm 58.35^{* *}$ & $575.48 \pm 4.39$ \\
\hline & $\mathrm{K}$ & $34196.34 \pm 55.05^{* *}$ & $28757.31 \pm 36.24$ \\
\hline & $\mathrm{Mg}$ & $1126.46 \pm 3.03^{* *}$ & $986.17 \pm 0.25$ \\
\hline & $\mathrm{P}^{\circ}$ & $674.65 \pm 4.41^{* *}$ & $3097.83 \pm 6.52$ \\
\hline & $\mathrm{Ca}$ & $1350.54 \pm 5.84^{* *}$ & $212.22 \pm 3.85$ \\
\hline \multirow{5}{*}{ Microelement } & $\mathrm{Fe}$ & $271.43 \pm 3.74^{* *}$ & $244.85 \pm 0.57$ \\
\hline & $\mathrm{Zn}$ & $45.8 \pm 1.63^{*}$ & $52.02 \pm 1.15$ \\
\hline & $\mathrm{Mn}$ & $17.42 \pm 0.28^{* *}$ & $27.33 \pm 0.27$ \\
\hline & $\mathrm{Se}$ & $2.21 \pm 0.09$ & ND \\
\hline & $\mathrm{Cu}$ & $18.45 \pm 0.56$ & $18.09 \pm 0.61$ \\
\hline
\end{tabular}

Notes. Results were expressed as means \pm SE $(n=3)$. ${ }^{*}$ Significant at 0.05 level. ${ }^{* *}$ Extremely significant at 0.01 level. "ND" represented it was not detected.

been linked to many human diseases, such as cardiovascular disease, cancer, male infertility, and abnormalities in immune and thyroid function [35]. So BFSR is a good dietary supplement for the Se element.

3.1.3. Vitamin Content. The result of vitamin composition is shown in Table 4 . Vitamins A, D, E, $K_{1}$, and $B_{1}$ could not be detected because their content might be less than relative detection limits. The contents of vitamins $\mathrm{B}_{2}, \mathrm{~B}_{5}, \mathrm{~B}_{6}$, folic acid, and nicotinic acid were significantly different between BFSR and GHSR except $B_{12}$. Vitamins of group B belong to the most important biologically active substances, as they ensure the normal performance of a human body through participation in the biosynthesis of proteins and functioning of the central nervous, cardiovascular, and gastrointestinal systems [36, 37]. But the human body cannot synthesize by itself and needs additional supplements. Therefore, BFSR and GFSR both can be used as important edible fungus for supplementing group B vitamins. In addition, nicotinic acid in BFSR $(385.39 \pm 3.98 \mathrm{mg} / 100 \mathrm{~g})$ was more than 3 times as much as that of GHSR $(103.92 \pm 0.76 \mathrm{mg} / 100 \mathrm{~g})$. Nicotinic acid is one of the naturally occuring $\mathrm{B}_{3}$ vitamins that acts as the precursor of $\mathrm{NAD}^{+} / \mathrm{NADH}$ and $\mathrm{NADP}^{+} / \mathrm{NADPH}$ and participates in many biochemical processes including lipid metabolism, tissue oxidation, glycolysis, and respiratory functions [38]. It is commonly used to improve animal performance and healthy growth. In this perspective, BFSR is better than GHSR in the nicotinic acid industry.

3.1.4. Amino Acid Composition. The content and percentage of amino acids in BFSR and GHSR are shown in Table 5. The results showed that 18 known amino acids all of which could be recorded in these two types of mushrooms in this study. In general, 7-17 kinds of known amino acids can be detected in mushrooms [39, 40], while 18 kinds contained in S. rugosoannulata.

In BFSR, the highest content of amino acid was isoleucine acid $(6.72 \pm 0.10 \mathrm{mg} / 100 \mathrm{~g})$ with the percentage of $35.45 \pm 0.65 \%$, 5 times more than reported [41], and GHSR $(0.98 \pm 0.00 \mathrm{mg} / 100 \mathrm{~g}, 5.79 \pm 0.03 \%)$. Isoleucine acid, a raw material for the synthesis of human peptide hormones and 
TABLE 4: Vitamin content of BFSR and GHSR.

\begin{tabular}{|c|c|c|}
\hline Vitamin & BFSR & GHSR \\
\hline Vitamin $A^{a}$ & $\mathrm{ND}(<10)$ & $\mathrm{ND}(<10)$ \\
\hline Vitamin $\mathrm{D}^{\mathrm{b}}$ & $\mathrm{ND}(<0.0007)$ & $\mathrm{ND}(<0.0007)$ \\
\hline Vitamin $\mathrm{E}^{\mathrm{b}}$ & ND $(<0.04)$ & ND $(<0.04)$ \\
\hline Vitamin $\mathrm{K}_{1}^{\mathrm{b}}$ & $\mathrm{ND}(<1.5)$ & $\mathrm{ND}(<1.5)$ \\
\hline Vitamin $\mathrm{B}_{1}{ }^{\mathrm{b}}$ & $\mathrm{ND}(<0.03)$ & $\mathrm{ND}(<0.03)$ \\
\hline Vitamin $\mathrm{B}_{2}{ }^{\mathrm{b}}$ & $1.77 \pm 0.15^{* *}$ & $2.68 \pm 0.03$ \\
\hline Vitamin $\mathrm{B}_{6}{ }^{\mathrm{b}}$ & $0.27 \pm 0.01^{* *}$ & $0.41 \pm 0.01$ \\
\hline Vitamin $\mathrm{B}_{12}{ }^{\mathrm{a}}$ & $0.39 \pm 0.02$ & $0.41 \pm 0.01$ \\
\hline Folic acida ${ }^{b}$ & $55.87 \pm 0.43^{* *}$ & $35.37 \pm 0.85$ \\
\hline Nicotinic acid ${ }^{\mathrm{b}}$ & $385.39 \pm 3.98^{* *}$ & $103.92 \pm 0.76$ \\
\hline Vitamin $\mathrm{B}_{5}{ }^{\mathrm{b}}$ & $14.37 \pm 0.32^{* *}$ & $11.17 \pm 0.26$ \\
\hline
\end{tabular}

Notes. Results were expressed as means \pm SE $(n=3) .{ }^{* *}$ Extremely significant at 0.01 level. "ND" represented it was not detected. ${ }^{a} \mu \mathrm{g} / 100 \mathrm{~g} .{ }^{b} \mathrm{mg} / 100 \mathrm{~g}$.

TABLE 5: Composition and content of amino acids of BFSR and GHSR.

\begin{tabular}{|c|c|c|c|c|}
\hline \multirow{2}{*}{ Amino acid ${ }^{\mathrm{a}}$} & \multicolumn{2}{|c|}{ BFSR } & \multicolumn{2}{|c|}{ GHSR } \\
\hline & Content $(\mathrm{mg} / 100 \mathrm{~g})$ & Percentage (\%) & Content $(\mathrm{mg} / 100 \mathrm{~g})$ & Percentage (\%) \\
\hline $\mathrm{Val}^{\mathrm{b}}$ & $0.87 \pm 0.03^{* *}$ & $4.58 \pm 0.17^{* *}$ & $1.18 \pm 0.01$ & $6.95 \pm 0.06$ \\
\hline $\mathrm{Met}^{\mathrm{b}}$ & $0.23 \pm 0.01^{* *}$ & $1.18 \pm 0.05^{* *}$ & $0.82 \pm 0.01$ & $4.88 \pm 0.03$ \\
\hline $\mathrm{Ile}^{\mathrm{b}}$ & $6.72 \pm 0.10^{* *}$ & $35.45 \pm 0.65^{* *}$ & $0.98 \pm 0.00$ & $5.79 \pm 0.03$ \\
\hline $\mathrm{Leu}^{\mathrm{b}}$ & $0.97 \pm 0.02^{* *}$ & $5.13 \pm 0.07^{* *}$ & $1.22 \pm 0.00$ & $7.21 \pm 0.01$ \\
\hline $\mathrm{Thr}^{\mathrm{b}}$ & $0.79 \pm 0.02$ & $4.16 \pm 0.04^{* *}$ & $0.81 \pm 0.01$ & $4.80 \pm 0.05$ \\
\hline $\mathrm{Phe}^{\mathrm{b}}$ & $0.87 \pm 0.03$ & $4.59 \pm 0.13$ & $0.83 \pm 0.01$ & $4.94 \pm 0.04$ \\
\hline Lys ${ }^{b}$ & $1.40 \pm 0.04^{* *}$ & $7.36 \pm 0.24^{* *}$ & $0.84 \pm 0.01$ & $4.98 \pm 0.04$ \\
\hline $\operatorname{Trp}^{\mathrm{b}}$ & $0.14 \pm 0.00$ & $0.71 \pm 0.02$ & $0.13 \pm 0.01$ & $0.75 \pm 0.04$ \\
\hline Asp & $0.56 \pm 0.04^{* *}$ & $2.96 \pm 0.17^{* *}$ & $1.74 \pm 0.01$ & $10.28 \pm 0.06$ \\
\hline Glu & $1.75 \pm 0.03^{* *}$ & $9.23 \pm 0.19^{* *}$ & $2.88 \pm 0.00$ & $17.07 \pm 0.02$ \\
\hline Ser & $0.53 \pm 0.01^{* *}$ & $2.80 \pm 0.02^{* *}$ & $0.72 \pm 0.01$ & $4.25 \pm 0.03$ \\
\hline Gly & $0.04 \pm 0.00^{* *}$ & $0.20 \pm 0.01^{* *}$ & $0.81 \pm 0.00$ & $4.82 \pm 0.02$ \\
\hline $\operatorname{Arg}^{c}$ & $0.05 \pm 0.01^{* *}$ & $0.27 \pm 0.05^{* *}$ & $0.88 \pm 0.00$ & $5.22 \pm 0.01$ \\
\hline Pro & $0.40 \pm 0.00^{* *}$ & $2.11 \pm 0.03^{* *}$ & $0.89 \pm 0.00$ & $5.28 \pm 0.02$ \\
\hline Ala & $1.44 \pm 0.03^{* *}$ & $7.58 \pm 0.14^{* *}$ & $1.12 \pm 0.00$ & $6.60 \pm 0.03$ \\
\hline Cys & $0.05 \pm 0.00^{* *}$ & $0.28 \pm 0.02^{* *}$ & $0.21 \pm 0.00$ & $1.26 \pm 0.02$ \\
\hline $\mathrm{His}^{\mathrm{c}}$ & $0.37 \pm 0.02$ & $1.96 \pm 0.01$ & $0.32 \pm 0.00$ & $1.91 \pm 0.01$ \\
\hline Tyr & $1.79 \pm 0.07^{* *}$ & $9.45 \pm 0.32^{* *}$ & $0.54 \pm 0.01$ & $3.16 \pm 0.04$ \\
\hline TFAA & $18.97 \pm 0.17^{* *}$ & 1 & $16.92 \pm 0.02$ & / \\
\hline EAA & $11.98 \pm 0.03^{* *}$ & I & $6.81 \pm 0.01$ & I \\
\hline NEAA & $6.99 \pm 0.15^{* *}$ & l & $10.11 \pm 0.01$ & l \\
\hline $\mathrm{E} / \mathrm{T}$ & $63.15 \%$ & I & $40.25 \%$ & l \\
\hline
\end{tabular}

Notes. Results were expressed as means \pm SE $(n=3) .{ }^{*}$ Significant at 0.05 level. ${ }^{* *}$ Extremely significant at 0.01 level. "a”: Valine (Val); methionine (Met); isoleucine (Ile); leucine (Leu); threonine (Thr); phenylalanine (Phe); lysine (Lys); tryptophan (Trp); aspartic acid (Asp); glutamic acid (Glu); serine (Ser); glycine (Gly); arginine (Arg); proline (Pro); alanine (Ala); cystine (Cys); histidine (His); and tyrosine acid (Tyr). "b" represented essential amino acid to human body. "c" represented essential amino acid to baby. "TFAA" represented total free amino acid. "EAA" represented essential amino acid. "NEAA" represented nonessential amino acid. "E/T" represented the proportion of essential amino acids to total free amino acids.

enzymes, has the effect of promoting protein synthesis and inhibiting its decomposition and plays an important role in muscle protein metabolism. It is often combined with leucine and valine acids to form amino acid infusions and amino acid oral agents, which has a significant effect on the treatment of cerebral coma, liver coma, kidney disease, etc., while isoleucine acid cannot be detected in most mushrooms but for BFSR.

An extremely significant difference was found in total free amino acid between BFSR $(18.97 \pm 0.17 \mathrm{mg} / 100 \mathrm{~g})$ and GHSR $(16.92 \pm 0.02 \mathrm{mg} / 100 \mathrm{~g})$. The total content of essential amino acids in BFSR $(11.98 \pm 0.03 \mathrm{mg} / 100 \mathrm{~g})$ was much higher than that of GHSR $(6.81 \pm 0.01 \mathrm{mg} / 100 \mathrm{~g})$, while the content of nonessential amino acid was much lower. According to the ideal protein model recommended by the
FAO/WHO [42], the ratios of essential amino acids to total free amino acids (EAA/TFAA) of a good-quality protein are about $40 \%$, and the ratios of essential amino acids to nonessential amino acids (EAA/NEAA) are more than $60 \%$. The EAA/TFAA values of BFSR and GHSR were $63.15 \%$ and $40.25 \%$, respectively. It can be seen that the amino acid composition of BFSR and GHSR meets the requirements of an ideal protein, especially GHSR. So S. rugosoannulata is a kind of edible fungus with high nutritional value.

3.2. Biologically Active Materials Content. As shown in Table 6, S. rugosoannulata was rich in active compounds. BFSR had a higher content of total polysaccharides 
TABLE 6: Biologically active material content of BFSR and GHSR.

\begin{tabular}{lcr}
\hline Biologically active materials (\%) & BFSR & GHSR \\
\hline Total flavonoids & $0.14 \pm 0.01$ & $0.16 \pm 0.01$ \\
Total polysaccharides & $12.60 \pm 0.57^{* *}$ & $8.82 \pm 0.09$ \\
Reducing sugars & $3.55 \pm 0.18$ & $3.24 \pm 0.05$ \\
Total triterpenoids & $1.44 \pm 0.01^{* *}$ & $1.15 \pm 0.02$ \\
\hline
\end{tabular}

Notes. Results were expressed as means \pm SE $(n=3)$. ${ }^{* *}$ Extremely significant at 0.01 level.

TABLE 7: Results of antibacterial tests of BFSR and GHSR.

\begin{tabular}{|c|c|c|c|c|c|c|c|c|c|}
\hline \multirow{2}{*}{ Bacteria } & \multirow{2}{*}{ Gram stain } & \multicolumn{2}{|c|}{ BFSRAe } & \multicolumn{2}{|c|}{ BFSREe } & \multicolumn{2}{|c|}{ GHSRAe } & \multicolumn{2}{|c|}{ GHSREe } \\
\hline & & $\mathrm{MIC}^{\mathrm{a}}$ & $\mathrm{MBC}^{\mathrm{a}}$ & $\mathrm{MIC}^{\mathrm{a}}$ & $\mathrm{MBC}^{\mathrm{a}}$ & $\mathrm{MIC}^{\mathrm{a}}$ & $\mathrm{MBC}^{\mathrm{a}}$ & $\mathrm{MIC}^{\mathrm{a}}$ & $\mathrm{MBC}^{\mathrm{a}}$ \\
\hline E. coli. & - & 0.0625 & 0.125 & 0.125 & 0.125 & 0.0625 & 0.125 & 0.25 & 0.5 \\
\hline E. faecalis & + & 0.0625 & 0.25 & 0.25 & 0.5 & 0.125 & 0.125 & 0.5 & 0.5 \\
\hline S. pneumoniae & - & 0.125 & 0.25 & 0.25 & 1 & 0.125 & 0.25 & 0.25 & 1 \\
\hline S. aureus & + & 0.25 & 1 & 2 & 4 & 0.25 & 0.5 & 1 & 2 \\
\hline P. aeruginosa & - & 0.5 & 1 & 1 & 2 & 0.125 & 0.5 & 2 & 4 \\
\hline S. typhimurium & - & 0.5 & 2 & 1 & 4 & 0.5 & 1 & 4 & 4 \\
\hline K. pneumoniae & - & 0.5 & 2 & 4 & 8 & 1 & 2 & 2 & 4 \\
\hline S. Dublin & - & 1 & 2 & 2 & 4 & 0.5 & 2 & 4 & 8 \\
\hline S. pyogenes & + & 2 & 4 & 4 & 8 & 4 & 8 & 8 & $>8$ \\
\hline S. maltophilia & - & 4 & 8 & 4 & 4 & 2 & 4 & $>8$ & $>8$ \\
\hline
\end{tabular}

Notes. E. coli. was Escherichia coli. E. faecalis was Enterococcus faecalis. S. pneumoniae was Streptococcus pneumoniae. S. aureus was Staphylococcus aureus. P. aeruginosa was Pseudomonas aeruginosa. S. typhimurium was Salmonella typhimurium. K. pneumoniae was Klebsiella pneumoniae. S. Dublin was Salmonella Dublin. S. pyogenes was Streptococcus pyogenes. S. maltophilia was Stenotrophomonas maltophilia. “+” was Gram-positive. "-” was Gramnegative. The positive controls were active against all bacteria (MIC range: $0.2-50 \mu \mathrm{g} / \mathrm{mL}$ ). ${ }^{a} \mathrm{mg} / \mathrm{mL}$. BFSRAe was aqueous extract of BFSR. BFSREe was ethanolic extract of BFSR. GHSRAe was aqueous extract of GHSR. GHSREe was ethanolic extract of GHSR.

$(12.60 \pm 0.57 \%)$ and triterpenoids $(1.44 \pm 0.01 \%)$ than GHSR . Polysaccharides are important functional biological macromolecules because of their significant benefit to human health such as antioxidant, antidiabetic, immunopotentiation, antitumor, anti-inflammatory, and hypoglycemic activities [43-45]. In particular, the fungal polysaccharides become a research hotspot $[46,47]$. Triterpenoids also have a wide range of biological activities such as anticancer, antihyperlipidemic, cardioprotective, antidiabetic, antiobesity, hepatoprotective, and anti-inflammatory capacities [48]. Therefore, BFSR should have higher medicinal values for people to eat or for pharmacy, inspite of no statistically significant difference in total flavonoid content $(0.14 \pm 0.01 \%)$ compared with GHSR $(0.16 \pm 0.01 \%)$. Furthermore, reducing sugars also had no significant difference.

\subsection{Pharmacological Activities}

3.3.1. Antibacterial Activity. The antibacterial activity of aqueous and ethanolic extracts of BFSR and GHSR showed low values of MICs from 0.0625 to $8 \mathrm{mg} / \mathrm{mL}$ except ethanolic extract of GHSR ( $>8 \mathrm{mg} / \mathrm{mL})$ as shown in Table 7. E. coli, E. faecalis, and $S$. pneumoniae were relatively more sensitive to both BFSR and GHSR extracts. They had the weakest inhibitory effect on S. maltophilia. Broadly, aqueous extract had stronger antibacterial activity than ethanolic extract. Besides, the MBC values were found to be equal to or 2 to 4 times higher than the MIC values.

In antibacterial susceptibility tests, MIC value less than $8 \mathrm{mg} / \mathrm{mL}$ for rude solvent extracts can be considered potentially therapeutically useful $[49,50]$. In this study, the
MIC values, ranging from 0.0625 to $8 \mathrm{mg} / \mathrm{mL}$, were less than $8 \mathrm{mg} / \mathrm{mL}$, which confirmed the existence of a significant activity against all microbes tested except GHSREe against S. maltophilia. Therefore, BFSR and GHSR both have a great potential to be used as therapeutic agents for some common infectious diseases. In addition, because of the susceptibility difference between Gram-positive and Gram-negative bacteria [51, 52], most antibacterial medicinal compounds are active against Gram-positive bacteria but few against Gramnegative ones. But in our study, a remarkable antibacterial activity was found on BFSR and GHSR on Gram-negative bacteria such as E. coli, S. pneumoniae, P. aeruginosa, S. typhimurium, and K. pneumoniae. Therefore, it can be used to develop new antibacterial drugs, especially against resistant Gram-negative strains.

3.3.2. Antioxidant Activity. Three different tests were carried out to evaluate the antioxidant properties of aqueous and ethanolic extracts of BFSR and GHSR, including scavenging activity on $\mathrm{ABTS}^{+}$radicals (measuring the decrease in $\mathrm{ABTS}^{+}$radical absorption after exposure to radical scavengers), ferric-reducing power (measuring the conversion of a $\mathrm{Fe}^{3+} /$ ferricyanide complex to the ferrous form), and $\beta$-carotene bleaching activity (measuring $\beta$-carotene absorption variance with time going by after exposure to antioxidants). According to Figure 1, all samples showed good antioxidant activities although weaker than the positive controls ( $V_{c}$ and BHT). The radical scavenging activity and reducing power of all samples increased with the increase in concentrations. The aqueous extracts revealed a higher antioxidant activity than 


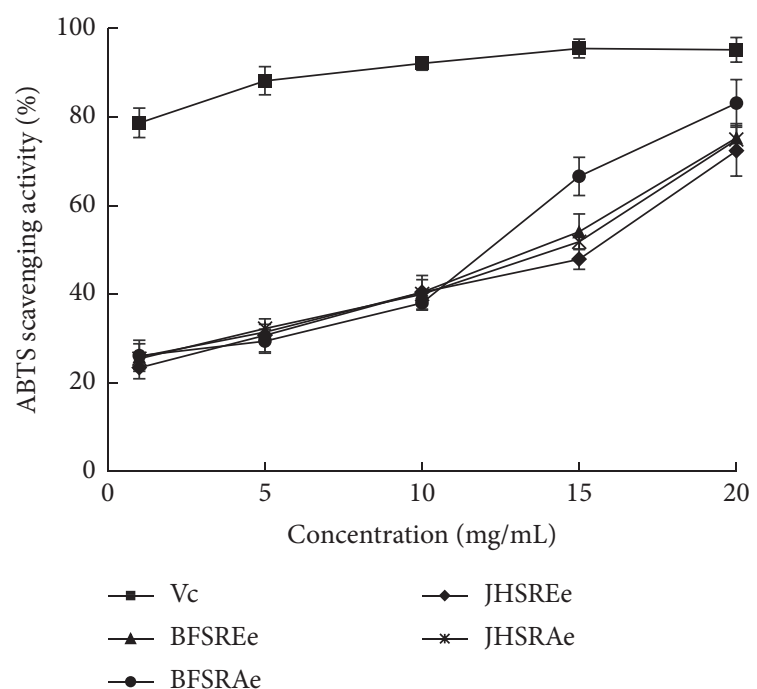

(a)

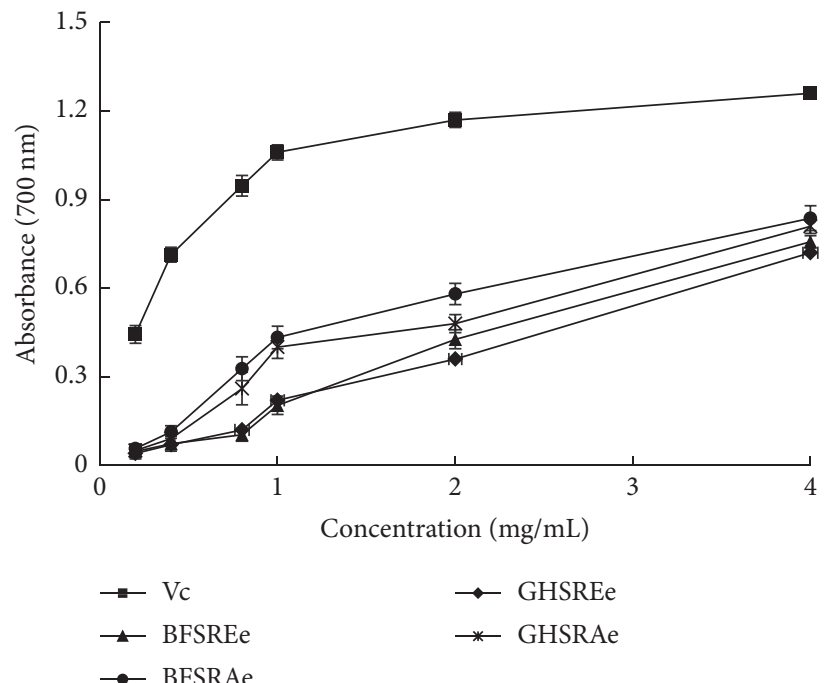

(b)

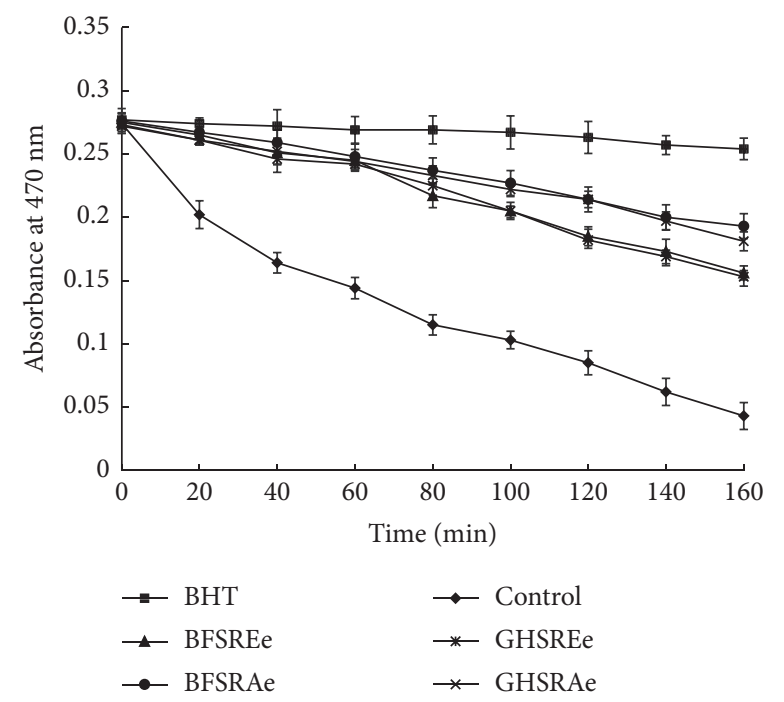

(c)

FIGURE 1: Antioxidant activity of BFSR and GHSR. Notes. (a) ABTS ${ }^{+}$radical scavenging activity. (b) Ferric-reducing power. (c) $\beta$-Carotene bleaching assay. BFSRAe was aqueous extract of BFSR. BFSREe was ethanolic extract of BFSR. GHSRAe was aqueous extract of GHSR. GHSREe was ethanolic extract of GHSR.

ethanolic extracts. The aqueous extracts of BFSR showed the highest $\mathrm{ABTS}^{+}$radical scavenging activity and reducing power, meanwhile the strongest inhibition of $\beta$-carotene bleaching.

\section{Conclusions}

From the above investigations, $S$. rugosoannulata, whether grown under the bamboo forest or cultivated in the greenhouse, can be used as nutrient sources due to their high content of protein, carbohydrate, fiber, and mineral, with low content of fat and $\mathrm{Na} / \mathrm{K}$ ratio. They are also rich in biologically active substances including polysaccharides, triterpenoids, and reducing sugars, which add great medicinal value to this mushroom. In addition, they are effective in antibacterial and antioxidant activities, while $S$. rugosoannulata grown under the bamboo forest is better than greenhouse one in some respects such as higher content of protein, calcium, selenium, nicotinic acid, folic acid, polysaccharides, and triterpenoids with stronger antibacterial and antioxidant activities. It is more appropriate for functional food and nutritional supplements.

\section{Data Availability}

The data used to support the findings of this study are available from the corresponding author upon request.

\section{Conflicts of Interest}

The authors declare that there are no conflicts of interest. 


\section{Authors' Contributions}

All the authors read and approved the final manuscript. Lei Wei and Bingnian Jing contributed equally to this article.

\section{Acknowledgments}

This study was financially supported by the Henan Major Public Welfare Projects (Code: 201300110200), the Outstanding Young Talents Training Program of Henan Academy of Sciences (Code: 220413008), and the Special Project for Guiding Local Scientific and Technological Development by the Central Government (211213004).

\section{References}

[1] W. Zhang, G. Tian, X. Geng et al., "Isolation and characterization of a novel lectin from the edible mushroom Stropharia rugosoannulata," Molecules, vol. 19, no. 12, pp. 19880-19891, 2014.

[2] W. A. Murrill, "Dark-spored agarics-II. Gomphidius and s Stropharia," Mycologia, vol. 14, no. 3, pp. 121-214, 1992.

[3] D. L. Hawksworth, P. M. Kirk, B. C. Sutton, and D. N. Pegler, Ainsworth \& Bisby's Dictionary of the Fungi, Oxford University Press, Oxford, UK, 1996.

[4] P. He, L. Geng, J. Wang, and C.-P. Xu, "Production, purfication, molecular characterization and bioactivities of exopolysaccharides produced by the wine cap culinary-medicinal mushroom, Stropharia rugosoannulata 2\# (higher basidiomycetes)," International Journal of Medicinal Mushrooms, vol. 14, no. 4, pp. 365-376, 2012.

[5] Y.-T. Liu, J. Sun, Z.-Y. Luo et al., "Chemical composition of five wild edible mushrooms collected from Southwest China and their antihyperglycemic and antioxidant activity," Food and Chemical Toxicology, vol. 50, no. 5, pp. 1238-1244, 2012.

[6] D. Domondon, J. Poppe, and L. Griensven, "Fruit optimization with wastes used for outdoor cultivation of King Stropharia," Neophilologus, vol. 79, no. 4, pp. 619-628, 2010.

[7] 2013 CUCEDH Cornell University Cooperative Extension and Department of Horticulture, Method for Cultivating Stropharia Mushrooms.

[8] S. Gong, S.-F. Zhao, Y. Nie, S.-C. Liu, X.-T. Zhang, and S.-X. Jiang, "Economic benifits of Stropharia rugosoannulata under different cultivation methods and conditions," Edible Fungi of China, vol. 35, no. 4, pp. 35-38, 2016.

[9] J. Zeng, "Interplanting technology of Stropharia rugosoannulata under fruit trees," Fujian Science \& Technology of Tropical Crops, vol. 38, no. 3, pp. 49-50, 2013.

[10] F.-J. Yang, C.-L. Zhang, C. Xie, and W.-W. Li, "Study on interplanting cultivation techniques of Stropharia rugoannulata and benefit analysis under the forest in the highland tropical," Modern Agricultural Sciences and Technology, vol. 000, no. 001, pp. 96-97, 2015.

[11] AOAC, Official Methods of Analysis, Association of Official Analytical Chemists, Arlington, VA, USA, 16th edition, 1995.

[12] M. J. Pozo, C. Cordier, E. Dumas-Gaudot, S. Gianinazzi, J. M. Barea, and C. Azcón-Aguilar, "Localized versus systemic effect of arbuscular mycorrhizal fungi on defence responses to Phytophthora infection in tomato plants," Journal of Experimental Botany, vol. 53, no. 368, pp. 525-534, 2002.

[13] M. Kaur and B. Asthir, "Characterization of biochemical and proximate composition in rice grains as influenced by germination," Cereal Research Communications, vol. 49, no. 2, pp. 291-299, 2021.

[14] M. Dubois, K. A. Gilles, J. K. Hamilton, P. A. Rebers, and F. Smith, "Colorimetric method for determination of sugars and related substances," Analytical Chemistry, vol. 28, no. 3, pp. 350-356, 1956.

[15] British Standards Institution (BSI), Soil Improvers and Growing Media. Extraction of Water Soluble Nutrients and Elements, pp. 12-24, BSI, London, UK, 2001.

[16] H. Qian and M. Sheng, "Simultaneous determination of fatsoluble vitamins $\mathrm{A}, \mathrm{D}$ and $\mathrm{E}$ and pro-vitamin $\mathrm{D}_{2}$ in animal feeds by one-step extraction and high-performance liquid chromatography analysis," Journal of Chromatography A, vol. 825, no. 2, pp. 127-133, 1998.

[17] C. K. Markopoulou, K. A. Kagkadis, and J. E. Koundourellis, "An optimized method for the simultaneous determination of vitamins B1, B6, B12, in multivitamin tablets by high performance liquid chromatography," Journal of Pharmaceutical and Biomedical Analysis, vol. 30, no. 4, pp. 1403-1410, 2002.

[18] B. J. Petteys and E. L. Frank, “"Rapid determination of vitamin B (riboflavin) in plasma by HPLC," Clinica chimica acta," International Journal of Clinical Chemistry, vol. 412, no. 1-2, pp. 38-43, 2010.

[19] H. Kim, Y. Choi, Y.-S. Cho, J. Sung, H. Ham, and J. Lee, "Comparison of extraction methods for determination of vitamin K1 in vegetables," Journal of the Korean Society of Food Science and Nutrition, vol. 43, no. 11, pp. 1791-1795, 2014.

[20] R. Mittermayr, A. Kalman, M. J. Trisconi, and O. Heudi, "Determination of vitamin $\mathrm{B}_{5}$ in a range of fortified food products by reversed-phase liquid chromatography-mass spectrometry with electrospray ionization," Journal of Chromatography A, vol. 1032, no. 1-2, pp. 1-6, 2004.

[21] L.-H. Wang, "Determination of nicotinic acid and metabolites in urine, cosmetics, and pharmaceuticals by high-performance liquid chromatography with novel electrochemical detection," Analytical Letters, vol. 49, no. 10, pp. 14671-21479, 2016.

[22] L. H. Robert and C. M. Stephen, "Amino acid analysis by reverse-phase high-performance liquid chromatography: precolumn derivatization with phenylisothiocyanate," Analytical Biochemistry, vol. 136, no. 1, pp. 65-74, 1984.

[23] Y. Shao and A. H.-M. Lin, "Improvement in the quantification of reducing sugars by miniaturizing the Somogyi-Nelson assay using a microtiter plate," Food Chemistry, vol. 240, pp. 898-903, 2018.

[24] N. Hudz, O. Yezerska, O. Grygorieva et al., "Analytical procedure elaboration of total flavonoid content determination and antimicrobial activity of bee bread extracts," Acta Poloniae Pharmaceutica-Drug Research, vol. 76, no. 3, pp. 439-452, 2019.

[25] T. Oludemi, L. Barros, M. A. Prieto, S. A. Heleno, M. F. Barreiro, and I. C. F. R. Ferreira, "Extraction of triterpenoids and phenolic compounds from Ganoderma lucidum: optimization study using the response surface methodology," Food \& Function, vol. 9, no. 1, pp. 209-226, 2018.

[26] C. Chen, L.-J. You, A. M. Abbasi, X. Fu, and R. H. Liu, "Optimization for ultrasound extraction of polysaccharides from mulberry fruits with antioxidant and hyperglycemic activity in vitro," Carbohydrate Polymers, vol. 130, pp. 122132, 2015.

[27] Clinical and Laboratory Standards Institute, Methods for Dilution Antimicrobial Susceptibility Tests for Bacteria that 
Grow Aerobically, Clinical and Laboratory Standards Institute, Wayne, PA, USA, Approved Standard, 8th edition, 2009.

[28] R. Re, N. Pellegrini, A. Proteggente, A. Pannala, M. Yang, and C. Rice-Evans, "Antioxidant activity applying an improved ABTS radical cation decolorization assay," Free Radical Biology and Medicine, vol. 26, no. 9-10, pp. 1231-1237, 1999.

[29] H.-B. Hu, H.-M. Li, M.-H. Han et al., "Chemical modification and antioxidant activity of the polysaccharide from Acanthopanax leucorrhizus," Carbohydrate Research, vol. 487, Article ID 107890, 2019.

[30] H. Ueno, S. Yamakura, R. S. Arastoo, T. Oshima, and K. Kokubo, "Systematic evaluation and mechanistic investigation of antioxidant activity of fullerenols using $\beta$-carotene bleaching assay," Journal of Nanomaterials, vol. 2014, no. 4, 7 pages, Article ID 802596, 2014.

[31] Q.-N. Yu, M.-J. Guo, B. Zhan, H. Wu, Y. Zhang, and L.-T. Zhang, "Analysis of nutritional composition in 23 kinds of edible fungi," Journal of Food Quality, vol. 2020, Article ID 8821315, 9 pages, 2020.

[32] NRC/NAS, Recommended Dietary Allowances, National Academy Press, Washington, DC, 1989.

[33] X.-H. Chen, L.-X. Xia, H.-B. Zhou, and G.-Z. Qiu, "Chemical composition and antioxidant activities of Russula griseocarnosa sp. Nov," Journal of Agricultural and Food Chemistry, vol. 58, no. 11, pp. 6966-6971, 2010.

[34] J. W. Choi, J.-S. Park, and C. H. Lee, "Interactive effect of high sodium intake with increased serum triglycerides on hypertension," PLoS One, vol. 15, no. 4, Article ID e0231707, 2020.

[35] H. Lai, T. Nie, Y. Zhang et al., "Selenium deficiency-induced damage and altered expression of mitochondrial biogenesis markers in the kidneys of mice," Biological Trace Element Research, vol. 199, no. 1, pp. 185-196, 2021.

[36] I. P. Antal, Y. R. Bazel, and Z. A. Kormosh, "Electrochemical methods for determining group B vitamins," Journal of Analytical Chemistry, vol. 68, no. 7, pp. 565-576, 2013.

[37] Z. M. Onyambu, M. P. Nawiri, H. N. Nyambaka, and N. M. Noah, "In vitro bioaccessibility of the vitamin B series from thermally processed leafy African indigenous vegetables," Journal of Food Quality, vol. 2021, Article ID 5540724, 8 pages, 2020.

[38] B. Zhang, J. Hao, H. Yin, C. Duan, B. Wang, and W. Li, "Effects of dietary nicotinic acid supplementation on meat quality, carcass characteristics, lipid metabolism, and tibia parameters of Wulong geese," Poultry Science, vol. 100, no. 11, Article ID 101430, 2021.

[39] S. Beluhan and A. Ranogajec, "Chemical composition and non-volatile components of Croatian wild edible mushrooms," Food Chemistry, vol. 124, no. 3, pp. 1076-1082, 2011.

[40] S. J. M. Mdachi, M. H. H. Nkunya, V. A. Nyigo, and I. T. Urasa, "Amino acid composition of some Tanzanian wild mushrooms," Food Chemistry, vol. 86, no. 2, pp. 179-182, 2004.

[41] S.-R. Li, L. Wang, S.-J. Ni, H.-H. Wang, X.-F. Liu, and C.-X. Liu, "The amino acids content of different part of Stropharia rugoso-annulata and their nutrition evaluation," Food Research and Development, vol. 38, no. 8, pp. 95-99, 2017.

[42] FAO, "Dietary protein quality evaluation in human nutrition; report of an FAO expert consultation," FAO, Rome, Italy, FAO Food and Nutrition Paper 92, 2013.

[43] Z. Zhang, F. Kong, H. Ni et al., "Structural characterization, $\alpha$-glucosidase inhibitory and DPPH scavenging activities of polysaccharides from guava," Carbohydrate Polymers, vol. 144, pp. 106-114, 2016.
[44] G. Chen, C. Fang, X. Chen, Z. Wang, M. Liu, and J. Kan, "High-pressure ultrasonic-assisted extraction of polysaccharides from Mentha haplocalyx: structure, functional and biological activities," Industrial Crops and Products, vol. 130, pp. 273-284, 2019.

[45] S. R. Thambiraj, M. Phillips, S. R. Koyyalamudi, and N. Reddy, "Yellow lupin (Lupinus luteus L.) polysaccharides: antioxidant, immunomodulatory and prebiotic activities and their structural characterisation," Food Chemistry, vol. 267, pp. 319-328, 2018.

[46] H. Alvandi, A. H. Zarmi, B. E. Hoseinzadeh, Z. B. MokhtariHosseini, and H. Aghajani, "Effect of production, extraction and purification methods on anti-cancer property of fungal polysaccharides," Developmental Biology, vol. 12, no. 1, pp. 21-30, 2020.

[47] H.-W. Hu, T. Xu, S.-S. Zhang, T.-T. Liu, X. Li, and D.-W. Wang, "Structural characteristics, rheological properties, and antioxidant activity of novel polysaccharides from "deer tripe mushroom"," Journal of Food Quality, vol. 2021, Article ID 6593293, 12 pages, 2021.

[48] H. Nguyen-Ngoc, T. K. Q. Ha, J.-L. Yang, H. T. T. Pham, and W. K. Oh, "Triterpenoids from the genus Gynostemma: chemistry and pharmacological activities," Journal of Ethnopharmacology, vol. 268, no. 4, Article ID 113574, 2020.

[49] W. Fabry, P. O. Okemo, and R. Ansorg, "Antibacterial activity of East African medicinal plants," Journal of Ethnopharmacology, vol. 60, no. 1, pp. 79-84, 1998.

[50] S. Gibbons, "Plants as a source of bacterial resistance modulators and anti-infective agents," Phytochemistry Reviews, vol. 4, no. 1, pp. 63-78, 2005.

[51] R. M. Herrera, M. Pérez, D. A. Martín-Herrera, R. LópezGarcía, R. M. Rabanal, and A. Arias, "Antimicrobial activity of extracts from plants endemic to the Canary Islands," Phytotherapy Research, vol. 10, no. 7, pp. 364-366, 1996.

[52] J. C. Meng, Q. X. Zhu, and R. X. Tan, "New antimicrobial mono-and sesquiterpenes from soroseris hookeriana subsp. erysimoides," Planta Medica, vol. 66, no. 6, pp. 541-544, 2000. 